\title{
Anxiety and depression level in working mothers who leave their children at home as compared to those who leave them at day care.
}

1. MBBS

House Officer Medicine

AMC/PGMI/LGH, Lahore.

2. FCPS (Medicine), MRCP (UK)

FRCP (Edin),

FRCP (Glasgow), FRCP (London), MCPS-HPE

Associate Professor Medicine AMC/PGMI/LGH, Lahore.

3. MBBS, FCPS (Gynae \& Obst)

Senior Registrar Gynae \& Obs AMC/PGMI/LGH, Lahore.

4. MBBS, DipCard

Registrar Medical Unit-III

AMC/PGMI/LGH, Lahore.

Correspondence Address:

Dr. Muhammad Imran Hasan Khan House No. 36 D, Model Town, Lahore. mimranhkhan@hotmail.com

Article received on: 29/07/2020

Accepted for publication:

$01 / 02 / 2021$
Fizza Zubair ${ }^{1}$, Muhammad Imran Hasan Khan ${ }^{2}$, Maryam Zulfiqar ${ }^{3}$, Salman Shakeel ${ }^{4}$

ABSTRACT... Objective: We aimed to find out the differences in degree of depression and anxiety experienced by working mother who leave their children at daycare as compared to those who leave them at home. Study Design: Cross Sectional Descriptive study. Setting: Lahore General Hospital Lahore. Period: October, 2019 to March, 2020. Material \& Methods: Through random sampling, 100 working mothers participated by filling a structured questionnaire after informed consent. It consisted of 50 women leaving their children at home and 50 women preferring day care centers while being on work. SPSS was used for analyzing the data. Beck Anxiety Inventory (BAI) and CES-D was used to calculate anxiety and depression levels respectively. Results: Mild to moderate depression and possibility of major depressive disorder along with moderate and severe anxiety is seen more in women leaving children at day care. Low and middle age, leaving kids at hand of maids, grandparents or day care or less educated family members, concerns regarding upbringing of children contribute to stress of working mothers. Our work shows that married women with their spouses develop more major depressive disorders and severe anxiety as compared to divorcees and widows. Nuclear and high-income families have more trend of leaving their children at day care. Conclusion: This study suggests that the women who leave their children at day care show increased rate of moderate and severe anxiety, mild to moderate depression and the possibility of major depressive disorders as compared to those leaving at home.

Key words: $\quad$ Beck Anxiety Inventory, Psychomotor Growth, Questionnaire.

Article Citation: Zubair F, Khan MIH, Zulfiqar M, Shakeel S. Anxiety and depression level in working mothers who leave their children at home as compared to those who leave them at day care. Professional Med J 2021; 28(07):944-950. https://doi.org/10.29309/TPMJ/2021.28.07.5844

\section{INTRODUCTION}

In recent years the role of women confined to wives and mothers have changed a lot. Occupation is a new role added, leading to burden of more responsibilities for working women. ${ }^{1}$ With their employment women face a series of interrelated role that are requiring each other and have equal expectations. ${ }^{2}$ Industrial era has failed to recognize the rapidly increasing pace of maternal employment. ${ }^{3}$ Nearly three-quarters of all mothers (more than sixty percent with young children) are in the labor force. ${ }^{4}$ Now along with being professionally sound they must also uphold the primary role at home. This reconciliation of house job and work job is more challenging and stressful. ${ }^{5}$ The most commonly reported cause of stress for working mothers was the lack of time to do everything. ${ }^{6}$ The strain is high especially at home when mother feel guilty for not giving much time to her child and husband while at work. ${ }^{7}$ This phenomenon is known as maternal separation anxiety, where mothers undergo unpleasant emotional state of mind for leaving their child even for short time period. ${ }^{8}$ According to Simith $\mathrm{H}$. C. 2003, the working mothers face much stress and anxiety while struggling to have a balanced family and profession. ${ }^{9}$

Being a mother, the main concern is the mental and physically upbringing of their children. ${ }^{10} \mathrm{~A}$ major part of children's' cognitive, affective and psychomotor growth takes place at an early age below three years. ${ }^{11}$ High quality care lead to cognitive and language development and academic achievement. ${ }^{12}$ In contrary, children attending daycare are less compliant and more 
assertive with their playmates. Although daycare can have a positive impact on child's cognitive and social development, one on one discipline and instruction at home is far more important. ${ }^{13}$

According to statistics about 22 percent women in Pakistan are currently in labor force. ${ }^{14}$ They just like rest of world population are prone to anxiety and depression level due to high work burden and responsibilities. ${ }^{15}$ But at the same time many factors differ from western culture. Considering the fact that state in west have taken responsibility and have taken a lot of steps. Establishment of day care centers especially with work place, paid leaves and guaranteed time off work are some examples. ${ }^{16}$ However, the family system is not that much strong in west as here in eastern countries. This give advantage to both working parents to leave their kids to some trustworthy relative. However, as rate of employment increases, mothers along with relatives are becoming unavailable to look after the child. Hence, day care centers are gaining popularity in Pakistan also. ${ }^{17}$ Therefore, working mothers are worried as to whether the upbringing of their child is more satisfactory at home or at day care centers.

The trend of women working outside home has prevailed since last decade in Pakistan. Hence literature lack in factors described in previous paragraph regarding Pakistani working mothers. Hence, we are interested in knowing the concerns of working mothers regarding the upbringing of their children. Their satisfaction level at leaving their children either at home or at day care or more precisely at the hands of relatives or nonrelatives in their absence. Moreover, Day care system has been shortly introduced in Pakistan. Little has been studied in Pakistan regarding the satisfaction level of mothers in leaving their kids at day care. Therefore, we conducted this research by randomly selecting working mothers. 50 who leave their children at home and 50 who leave them at day care while at work. We tried to determine the measures that can be taken to eliminate the reservations and concerns of mothers towards leaving their children so that they can perform better both at employment and maternal duty with free calm mind as much as possible.

\section{MATERIAL \& METHODS}

It was a cross sectional descriptive study held at Lahore General Hospital. It took approximately 6 months from October, 2019 to March, 2020. Sample size was 100 which was randomly collected from working women from different professions. It consisted of 50 women leaving their children at home and 50 women preferring day care centers while being on work. Variables such as Age of mother; Qualification of mother; Marital status; Type of family; Profession of mother; Profession of husband; financial status; number of children with their age; were collected via a structured questionnaire after informed consent. Ethical approval was taken from ethical review committee of Lahore General Hospital, Lahore. Inclusion criteria was any mother working part time or full time. Anxiety was assessed using Beck Anxiety Inventory (BAI). The total score is calculated by finding the sum of the 21 items. Score of 0-21 = low anxiety Score of 22$35=$ moderate anxiety Score of 36 and above $=$ potentially concerning levels of anxiety;: ${ }^{18}$ As a depression screening tool, the 20 item CES-D was used. Scores $<15$ carry no indication that a depressive disorder exists, however, further monitoring is recommended. Scores between 15 and 21 are indicative of mild to moderate depression. Scores above 21 indicate severe/ major depression and the initiation of therapeutic measures is compulsory. ${ }^{19}$ The data was entered and analyzed through the SPSS statistical package. The results were obtained using cross tables. Chi square test was applied to confirm whether the difference is significant or not.

\section{RESULTS}

Moderate and severe anxiety is seen more in women leaving children at day care while low anxiety is seen more in women leaving their children at home. Mild to moderate depression and possibility of major depressive disorder is seen more in women leaving children at day care.

We have also tried to evaluate the causes of anxiety and depression. Our study has shown that its causes are multiple including: low and 
middle age group, leaving kids at hand of maids or day care or less educated family members, marital status, concerns regarding mental and physical upbringing of children.

Our work shows that married women with their spouses show more tendency to develop major depressive disorders and severe anxiety as compared to divorcees and widows. Nuclear families tend to leave their children at day care more as compared to extended families. The trend of leaving kids at day care increases as the income of parents increases. Possibility of major depressive disorder is high among females who leave their children with grandparents.

Mothers who leave their children at day care reported hygiene issues and language impairment of their children while those leaving kids at home are concerned about their meal timings, improper care and education of children at the hand of old less educated grandparents.

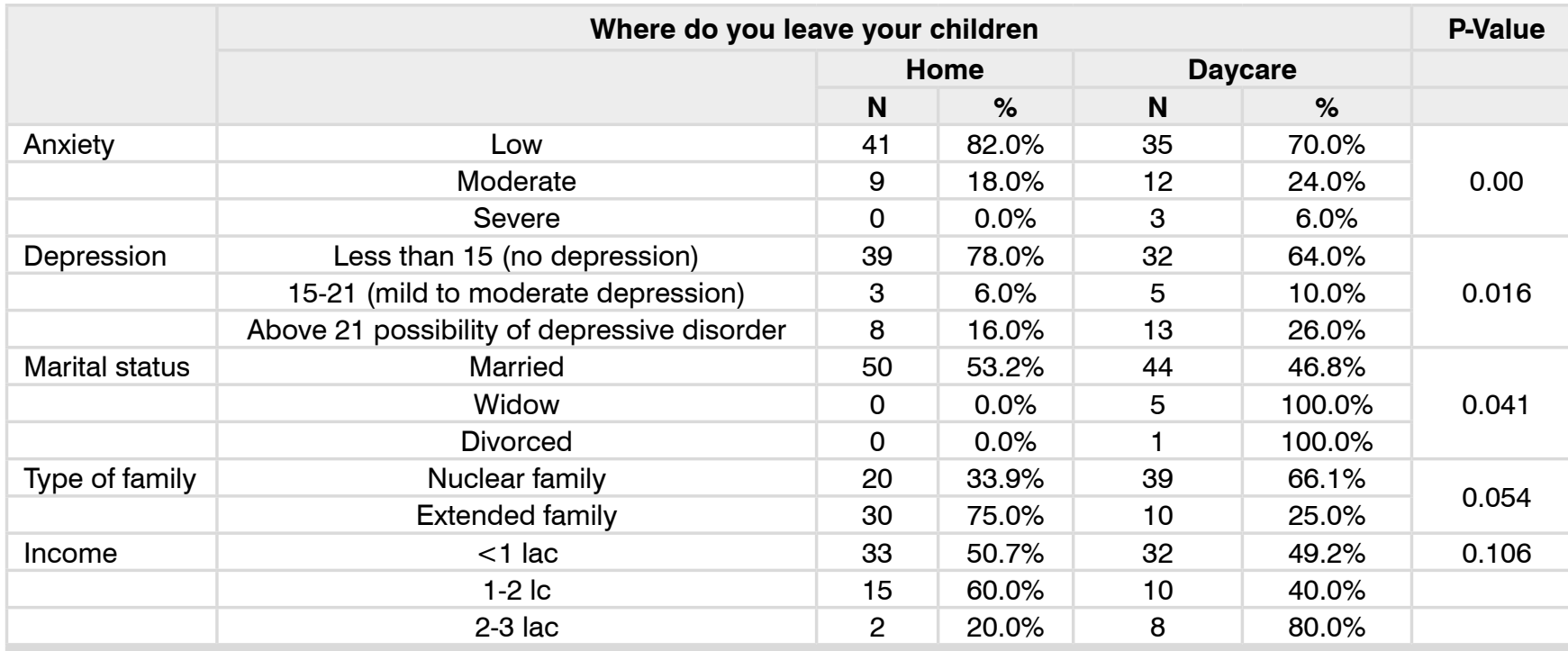

Table-I. Comparison of variables in working women who leave their children at home as compared to those who leave them at day care.

\begin{tabular}{|c|c|c|c|c|c|}
\hline & & \multicolumn{3}{|c|}{ Anxiety } & \multirow[t]{2}{*}{ P-Value } \\
\hline & & $0-21$ low & 22-35 moderate & $36-100$ severe & \\
\hline \multirow{6}{*}{ Age } & $18-30$ & 40 & 10 & 3 & \multirow{4}{*}{0.250} \\
\hline & & $75.5 \%$ & $18.9 \%$ & $5.7 \%$ & \\
\hline & $31-42$ & 27 & 11 & 0 & \\
\hline & & $71.1 \%$ & $28.9 \%$ & $0.0 \%$ & \\
\hline & $43-54$ & 9 & 0 & 0 & \\
\hline & & $100.0 \%$ & $0.0 \%$ & $0.0 \%$ & \\
\hline \multirow[t]{6}{*}{ Person With Kids at home } & Maid & 4 & 1 & 0 & 0.147 \\
\hline & & $80.0 \%$ & $20.0 \%$ & $0.0 \%$ & \\
\hline & Grand parents & 28 & 7 & 0 & \\
\hline & & $80.0 \%$ & $20.0 \%$ & $0.0 \%$ & \\
\hline & Others & 9 & 0 & 0 & \\
\hline & & $100.0 \%$ & $0.0 \%$ & $0.0 \%$ & \\
\hline \multirow[t]{6}{*}{ Marital status } & Married & 71 & 20 & 3 & 0.825 \\
\hline & & $75.5 \%$ & $21.3 \%$ & $3.2 \%$ & \\
\hline & Widow & 4 & 1 & 0 & \\
\hline & & $80.0 \%$ & $20.0 \%$ & $0.0 \%$ & \\
\hline & Divorced & 1 & 0 & 0 & \\
\hline & & $100.0 \%$ & $0.0 \%$ & $0.0 \%$ & \\
\hline
\end{tabular}

Table-II. Assessing severity of anxiety in different variables 


\begin{tabular}{|c|c|c|c|c|c|}
\hline & & \multicolumn{3}{|c|}{ Depression } & \multirow[t]{2}{*}{ P-Value } \\
\hline & & $\begin{array}{l}\text { Less than } 15 \\
\text { (no Depression) }\end{array}$ & $\begin{array}{l}15-21 \text { (mild to } \\
\text { moderate) }\end{array}$ & $\begin{array}{l}\text { Above } 21 \text { possibility of } \\
\text { depressive disorder }\end{array}$ & \\
\hline \multirow[t]{6}{*}{ Age } & $18-30$ & 36 & 4 & 13 & \multirow{4}{*}{0.500} \\
\hline & & $67.9 \%$ & $7.5 \%$ & $24.5 \%$ & \\
\hline & $31-42$ & 27 & 4 & 7 & \\
\hline & & $71.1 \%$ & $10.5 \%$ & $18.4 \%$ & \\
\hline & $43-54$ & 8 & 0 & 1 & \\
\hline & & $88.9 \%$ & $0.0 \%$ & $11.1 \%$ & \\
\hline \multirow[t]{6}{*}{ Person With Kids at home } & Maid & 4 & 1 & 0 & 0.316 \\
\hline & & $80.0 \%$ & $20.0 \%$ & $0.0 \%$ & \\
\hline & Grand parents & 26 & 1 & 8 & \\
\hline & & $74.3 \%$ & $2.9 \%$ & $22.9 \%$ & \\
\hline & Others & 8 & 1 & 0 & \\
\hline & & $88.9 \%$ & $11.1 \%$ & $0.0 \%$ & \\
\hline \multirow[t]{6}{*}{ Marital status } & Married & 66 & 8 & 20 & 0.798 \\
\hline & & $70.2 \%$ & $8.5 \%$ & $21.3 \%$ & \\
\hline & Widow & 4 & 0 & 0 & \\
\hline & & $80.0 \%$ & $0.0 \%$ & $0.0 \%$ & \\
\hline & Divorced & 1 & 1 & 0 & \\
\hline & & $100.0 \%$ & $20.0 \%$ & $0.0 \%$ & \\
\hline
\end{tabular}

\section{DISCUSSION}

With the advancing socio-economic development in Pakistan the trend of working women is increasing day by day. Being absent from home while on work, the question as to whether the upbringing of their children is better at daycare or at home continuously worries the minds of working mothers. Multiple researches show anxiety and depression levels in working mothers more than working fathers. ${ }^{13}$ About $91 \%$ of working moms suffered some symptoms of depression. ${ }^{20}$ It is recognized that the development of a woman's emotional attachment to her infant is closely linked to psychological adjustment and maternal mental health. ${ }^{21}$ The most frequently reported source of stress for working mothers was not having enough time to do everything. ${ }^{9}$

In our paper mild to moderate depression and possibility of major depressive disorder along with moderate and severe anxiety levels are seen more in women leaving children at day care.
Our study has shown multiple causes of anxiety and depression: age, the person with which women are leaving their children at home, marital status, mental and physical upbringing of children.

Women between 18-30 years suffer more from anxiety and from possibility of major depressive disorder. As age advances rate of anxiety decreases. Our study shows that mild to moderate depression is seen more in middle age women between 31-42 years. A new report finds that one in eight middle-age women in the US has depression. ${ }^{22}$

It has been observed through this study that 22.9\% women who leave their children with grand parents have shown possibility of major depressive disorder and low to moderate level of anxiety. Dr. Terri Apter is a psychologist and academic in the field of family dynamics. Her 20 years of study of families provides insight that $60 \%$ of mother in law/daughter in law bonds are 
described in strong negative terms. ${ }^{23}$

Akinbode (2002) viewed that working mother regardless of their marital status face different stress levels. ${ }^{7}$ In contrary to this our work shows that married women with their spouses show more tendency to develop major depressive disorders and severe anxiety as compared to divorcees and widows.

Mothers who leave their children at day care reported hygiene issues and language impairment of their children while those leaving kids at home are concerned about their meal timings, improper care and education of children at the hand of old less educated grandparents. Being a mother, main strain is the concern of child's upbringing both mentally and physically. ${ }^{10}$ As it is shown by research an infant's attachment to his mother leads to optimal psychological development. ${ }^{24}$ In contrary, poor attachment in early childhood are predictive of adverse socioemotional development, and poorer behavioral and cognitive outcomes. ${ }^{25}$

We have also tried to evaluate the reason of leaving children at daycare. The trend of leaving children at day care is more seen among nuclear and high-income families.

It is seen that trend of leaving children is more in widows and divorced women. A research showed that absence of spouse increases the level of stress to mothers regarding their kids. One might expect the absence of a working husband from household would be a major explanation of increase in demand of daycare while mothers are at work. ${ }^{26}$

In the light of this study we concluded that the women who leave their children at day care show increased rate of moderate and severe anxiety and mild to moderate depression as compared to those women who leave their children at home. Hence, we recommendation that measures should be taken to decrease the level of anxiety and depression in working mothers. Working hours of mothers should be reduced with a good pay so that they can spend time with their family as well as support them financially. Legislation should be made that every work place must establish a proper daycare center with it. This will allow mothers to feed their kids and spend some time with them during working hours. Government should ensure that every day care established must be safe and give proper environment to children. Government should establish its own quality day care on cheaper rates.

There were some limitations in our study such as we took sample of working mothers of Lahore only. The result may not reflect truly the working mothers of Pakistan as a whole as mothers in big and small cities tend to face different circumstances and challenges both at work place and at home. Our study didn't equally represent all the professions. It may lead to some biasness as there is different nature of each job with resulting challenges. We believe that another research with a larger sample size and less biased grouping of sample size must be conducted for better results.

\section{CONCLUSION}

This study suggests that the women who leave their children at day care show increased rate of moderate and severe anxiety as compared to those $w$ at home. Similarly, mild to moderate depression and the possibility of major depressive disorders are more in women leaving their children at day care as compared to those leaving at home.

\section{Copyright $@$}

\section{REFRENCES}

1. Haddadi M, Chaldi A, Sajjadi H, Salehi M. Relationship between occupational class and mental health in women. J Soc Welf. 2011; 11:107-27.

2. Ahmadifaraz M, Foroughipour A, Abedi $\mathrm{H}$, Azarbarzin $\mathrm{M}$, Dehghani L, Meamar R. Anxiety of women employees and the process of maternal role. Int J Prev Med. 2013 May; 4(Suppl 2):S262-9.

3. Piotrkowski CS, Rapoport RN, Rapoport R. Families and Work. In: Sussman MB, Steinmetz SK, editors. Handbook of Marriage and the Family [Internet]. Boston, MA: Springer US; 1987 [cited 2020 Jul 26]. p. 251-83. Available from: https://doi.org/10.1007/978-14615-7151-3_10. 
4. Ekta, Mittal R. Disciplinary techniques adopted by working and non-working mothers. Res $\mathrm{J}$ Humanit Soc Sci. 2017; 8(3):267.

5. Anderson-Kulman RE, Paludi MA. Working mothers and the family context: Predicting positive coping. $J$ Vocat Behav. 1986 Jun 1; 28(3):241-53.

6. At B. Ward $\mathrm{CH}$. Mendelson M. Mock J. Erbaugh J. An inventory for measuring depression. Arch Gen Psychiatry. 1961; 4(561-571):3.

7. Akinbode GA, Ayodeji F. Gender and family characteristics differences in work-family, familywork conflicts and stress among dual-income earners families: (An empirical analysis in cosmopolitan Lagos, Nigeria). Gend Behav. 2017; 15(3):9424-53.

8. Heightened maternal separation anxiety in the postpartum: The Role of Socioeconomic Disadvantage - Amanda R. Cooklin, Nina Lucas, Lyndall Strazdins, Elizabeth Westrupp, Rebecca Giallo, Louise Canterford, Jan M. Nicholson, 2014 [Internet]. [cited 2020 Jul 26].

9. Sizane NF, Rensburg E van. Night shift working mothers: Mutual perceptions with adolescent children. J Psychol Afr. 2011 Jan 1; 21(1):71-8.

10. Responsibilities of motherhood [Internet]. [cited 2020 Jul 26]. Available from: https://healthfully.com/81853responsibilities-motherhood.html

11. The stay-at-home mom vs. the working mom | WeHaveKids [Internet]. [cited 2020 Jul 26].

12. Academic and cognitive functioning in first grade: Associations with earlier home and child care predictors and with concurrent home and classroom experiences: School Psychology Review: Vol 35, No 1 [Internet]. [cited $2020 \mathrm{Jul} 26$ ].

13. Hoffman LW. Work, family, and the child. In: Psychology and work: Productivity, change, and employment. Washington, DC, US: American Psychological Association; 1986. p. 173-220. (The Master lectures, Vol. 5.).

14. Sadaqat M, Sheikh Q. Employment situation of women in Pakistan. Int J Soc Econ. 2011 Jan 11; 38:98-113.
15. Women's mental health in Pakistan [Internet]. [cited 2020 Jul 27].

16. Orloff A. What can government do to support employed mothers? [Internet]. Scholars Strategy Network. [cited 2020 Jul 27].

17. Revolutionizing babysitting: Daycares in Pakistan The Express Tribune [Internet]. [cited 2020 Jul 27].

18. Beck anxiety inventory [Internet]. [cited $2020 \mathrm{Jul} 26$ ].

19. CES-D scale calculator [Internet]. MDApp. [cited 2020 Jul 26]. Available from: https://www.mdapp.co/ces-dscale-calculator-171/

20. Work life and mental wellbeing of single and nonsingle working mothers in Scandinavia - Torill Bull, Maurice B. Mittelmark, 2009 [Internet]. [cited 2020 Jul 26].

21. Mercer RT. The process of maternal role attainment over the first year. Nurs Res. 1985; 34(4):198-204.

22. Sanoveriana ASN, Fourianalistyawati E. Work-Family balance, trait mindfulness and psychological wellbeing in middle-aged working parents. UI Proc Soc Sci Humanit [Internet]. 2017 Apr 27 [cited 2020 Jul 26]; 1(0). Available from: http://proceedings.ui.ac.id/index. php/uipssh/article/view/63

23. Family matters: Learning to love your in-laws | Terri Apter Ph.D [Internet]. [Cited 2020 Jul 26]. Available from: https://terriapter.com/2017/10/20/family-matterslearning-to-love-your-in-laws/.

24. The nature of the child's tie to his mother - PubMed [Internet]. Cited 2020 Jul 26

25. The effect of parent-child attachment relationships on child biopsychosocial outcomes: A review: Early child development and care: Vol 178, No 2 [Internet]. [Cited 2020 Jul 26].

26. Tanaka Y, Nakazawa J, Nakazawa S. The effects of long-term husband absence on wives' stress: A cross-sectional and longitudinal study. Shinrigaku Kenkyu. 2000 Dec; 71(5):370-8. 


\section{AUTHORSHIP AND CONTRIBUTION DECLARATION}

\begin{tabular}{|c|c|c|c|}
\hline Sr. \# & Author(s) Full Name & Contribution to the paper & Author(s) Signature \\
\hline 1 & Fizza Zubair & $\begin{array}{l}\text { Original idea, Reivew of literature, } \\
\text { Initial manuscript writing, Final } \\
\text { review. }\end{array}$ & \\
\hline 2 & M. Imran Hasan Khan & $\begin{array}{l}\text { Introduction writing, Material } \\
\text { and Methods writing, Discussion } \\
\text { Review, Resutls review, Limitations, } \\
\text { Statistical analysis review, Final } \\
\text { manuscript approval. }\end{array}$ & \\
\hline 3 & & $\begin{array}{l}\text { Data collection, Approval from ERC, } \\
\text { Final approvalmanuscript. }\end{array}$ & \\
\hline 4 & Salman Shakeel & $\begin{array}{l}\text { Statistical analysis, Discussion } \\
\text { contribution, Final approval of } \\
\text { manuscript. }\end{array}$ & \\
\hline
\end{tabular}

